\title{
The effect of principal's leadership, school climate and teaching-learning process on economics learning outcomes
}

\author{
Nurhasanah', Syamsul Amar ${ }^{2}$, Idris ${ }^{3}$ \\ ${ }^{123}$ Universitas Negeri Padang, Padang - Indonesia, (hanifa.syahira88@gmail.com)
}

\begin{abstract}
This research was aimed to find and anlyze: (1) the effect of principal's leadership and school climate on economics learning outcomes of students at state senior high schools (hereinafter SMA N) in Padang City and (2) the effect of principal's leadership, school climate and teaching-learning process on economics learning outcomes of students at SMA N in Padang City. This study belongs to descriptive causal research design. Research population were 62 economics teachers and the sample are 32 economics teachers. Result of this research found that, (1) Principal's leadership and school climate had a significant effect on economics learning outcomes of students at SMA N in Padang City. (2) Principal's leadership, school climate and teaching-learning process significantly affect economics learning outcomes of students at SMA N in Padang City.
\end{abstract}

Keywords : principal's leadership, school climate, teaching-learning process, learning outcomes Padang.

\section{Introduction}

Development of a country significantly relates to the role of education. Education serves as a catalyst of development in other fields such as in economics. Therefore, all countries are competing to establish a qualified and enquitable education system. Various policies are made to develop education quality including curriculum improvement policy. Moreover, for years government has been improving the regulation of education implementation such as commitment budget, decentralization of education, and others. Through decentralization of education, each region is expected to have ample opportunity to develop education according to its resources.

Education quality can be seen from many factors. One of them is the quality of graduates. One of indicators that determine the quality of graduates is students' cognitive mastery that reflects on their scores. A school is considered successful in managing educational process when students graduate with a high score. Therefore, all schools are competing to improve their students' score especially the score of subjects tested national examination (UN)

To improve national education quality, Indonesia government makes national education standarization policy which sets national graduation standards. Despite pros and cons of the policy, the 
government has been developing the policy, for example, through raising graduation standards from year to year. This is done so that the school can improve students' achievement and the students can graduate with high UN scores.

Education quality is affected by some factors such as principal's leadership, school climate, teachinglearning process, motivation and others. Principal's leadership is the factor that governs the implementation of education in school. Principal is the manager of school organization who is going to optimize all school resources for the sake of good and qualified education so that teachers and students will have better teaching-learning process.

Wahyudi (2009:190) stated that leadership is the ability of empowering subordinates/members that initiates them to be creative in working in order to get good and meaningful result for the organization. A leader is considered successful if $\mathrm{s} /$ he is able to lead others' behaviour to desired goals of an organization. In other words, school principal is the one who is expected to be able to manage available resources in the school in order to achieve anticipated education quality.

Frequent replacement of the principal will negatively impact a leadership performance. The program planned by the principal has not been fully implemented but then they have to be replaced. For example, in a school in padang there was a principal who officiated less than two years. This case certainly affected the leadership performance in the school in general.

Next factor that affect education quality is school climate. School climate emphasizes nice atmosphere in school, not only about its physical condition but also all internal aspects of the organization, said Castetter in wufiani (2009:76). In addition, Mulyasa (2011:90) explained that a good performance of the principal can create a condusive school climate. It is shown by a safe, comfortable and orderly learning environment that results in an effective learning process. So, a good school climate will make teacher and students happy to do school activities so that teaching-learning process can be carried out as planned.

A good school climate is also indicated by good interpersonal relationship between school residents like between principal and teachers, between teachers and teachers, and between teachers and students. If there is a disharmony between school members, it will badly affect the learning process. Based on preliminary observation, it was found that the conflict arised between teachers regarding teaching timetables. This condition will also affect the amenities in work environment.

\section{Method}

Based on the problem obove, the researcher conducted a descriptive causal research which is suitable for studying the problem. The data was collected from respondents by using questionnaire. The data was then presented descriptively and analyzed to examine proposed hypothesis.

The population of this research ere 62 economics teachers from 16 state senior high schools in Padang City. To collect the data, the researcher used questionnaire as the instrument which was based on Likert scale. The questionnaire was arranged based on the indicators representing each variable.

Technique of data analysis was an inductive analysis. In path analysis, there is prequisite testing of the analysis which consists of (1) Normality test which aims to determine whether the data is normally distributed, and (2) Homogeneity test which aims to find whether the data has homogeneity of variance. Path analysis was used in order to find the effect of exogenous variables on other endogenous variables (variable intervening). 


\section{Result and Discussion}

This research was conducted by considering path analysis technique. Obtained data was processed by SPSS 18.0 to find the effect of exogenous variable on endogenous variable. Path analysis is divided into 2 sub structures of analysis:

Sub Structure 1. Effect of principal's leadership ( X1) and school climate (X2) on teaching-learning process $(\mathrm{X} 3)$

In sub structure 1 , the researcher discusess about the effect of $X 1$ variable of principal's leadership and $\mathrm{X} 2$ variable of school climate on result variable of teaching-learning process (X3) where $\mathrm{X} 3$ acts as intervening variable. The result of data processing can be seen in the following table:

Table 1. Path coefficient of variables of principal's leadership (X1) and school climate (X2) on teaching-learning process $(\mathrm{X} 3)$

\begin{tabular}{cccc}
\hline Model & Standardized Coefficients & $\mathrm{t}$ & Sig \\
\hline X1 & Beta & & \\
\hline X2 &, 396 & 2,588 &, 015 \\
\hline &, 366 & 2,393 &, 023 \\
\hline
\end{tabular}

Note: Dependent Variabel : X3

From the data in table, a partial testing was done on each causal variable on result variable in order to know the path direction.

a. Analysis result showed path coefficient of $P x_{3 \times 1}$ was 0,396 with a sig level $0,15<$ a of 0,05 . This indicates that path coefficient of effect of principal's leadership (X1) on teaching-learning process (x3) is significant. In other words, the better principal's leadership is, the better teaching-learning process will be.

b. The analysis also showed that path coefficient of PX3X2 is 0,366 in significance level of $0,023<$ a of 0,05 . This also indicate that there is a significant effect of school climate (X2) on teaching-learning process (X3). It means that a better school climate will create a better teaching-learning process in school.

c. Effect of other variables.

d. To calculate the effect of other variables, following formula is used:

$$
\begin{aligned}
\mathrm{PX}_{3 \varepsilon^{1} 1} & =\sqrt{ } 1-\mathrm{R}^{2} \mathrm{Y}_{11 \times 2} \\
& =\sqrt{ } 1-0,335 \\
& =\sqrt{ } 0,665 \\
& =0,815
\end{aligned}
$$

From the calculation, it is known that the effect of other variables on teaching-learning process (X3) scored $81,55 \%$. .

Based those data, path coefficients of variables can be summarized in the following equation:

$\mathrm{X} 3=\mathrm{P}_{3 \times 1} \mathrm{X}_{1}+\mathrm{P}_{3} \mathrm{x}_{2} \mathrm{X}_{2}+\mathrm{P} \times_{3} \mathcal{E}_{1}$

$=0,396 \mathrm{X} 1+0,366 \mathrm{X} 2+0,815$

Sub Structure 2. The Effect of Principal's Leadership (X1), School Climate (X2) and Teaching-Learning Process (X3) on Learning Outcomes (Y) 
Second testing was done to analyze the effect of causal variables of principal's leadership (X1), school climate (X2) and teaching-learning process (X3) on the result variable (Y), both partial and simultaneous. The result of testing is presented in table 2 below:

Table 2. ANOVAa

\begin{tabular}{cccccc}
\hline Model & Sum of Squares & Df & Mean Square & F & Sig \\
\hline Regression & 173,157 & 3 & 57,719 & 14,527 &, $000^{\mathrm{b}}$ \\
Residual & 111,252 & 28 & 3,973 & & \\
Total & 284,409 & 31 & & & \\
\hline
\end{tabular}

Note: - Dependent variable: $Y$

- Predictors : (constant), $\mathrm{X}_{3}, \mathrm{X}_{2}, \mathrm{X}_{1}$

From the table above, it can be seen that the value of $\mathrm{F}$ test is 14,527 and has sig probability value of 0,000 . Since the value of sig is smaller than 0,05 , then Ho is rejected and Ha is accepted . Thus, variables of $\mathrm{X} 1, \mathrm{X} 2, \mathrm{X} 3$ simulataneously has significant effect on $\mathrm{Y}$ variable. Next, a partial testing was done by conducting $\mathrm{t}$ test. The result of $\mathrm{t}$ test is presented in detail in the following table:

Table 3. $\mathrm{t}$ test coefficientsa

\begin{tabular}{cccc}
\hline Model & Standardized Coefficients & $\mathbf{t}$ & Sig \\
\cline { 2 - 4 } & Beta & & \\
$\mathbf{X}_{1}$ &, 414 & 3,119 &, 004 \\
$\mathbf{X}_{2}$ &, 281 & 2,148 &, 041 \\
$\mathbf{X}_{3}$ &, 340 & 2,342 &, 027 \\
\hline
\end{tabular}

Note: Y (dependent variable)

T test scores of exogenous variables on endogenous variable in table 2 are described as follows:

a. The effect of variable of principal's leadership (X1) on economics learning outcomes $(\mathrm{Y})$

Based on the obtained result of analysis, Pyx1 score is 0,414 in sig probability 0.04 value which is smaller than 0.05 . This describes a significant effect of $\mathrm{X} 1$ variable on $\mathrm{Y}$ variable. In other words, a better principal's leadership will create a better learning outcomes, in this case in economics subject in SMA N in Padang City.

b. The effect of school climate (X2) on student's learning outcomes (Y)

The result shows that the score of PYX2 is 0.281 in probability of sig 0,041 which is smaller that 0.05. This means that school climate significantly affects student's learning outcomes (Y). the better school climate is, the better students' learning outcomes will be in economics sucject at SMA N in Padang City.

c. The effect of variable of teaching-learning process $\left(X_{3}\right)$ on student's learning outcomes $(Y)$

The result of data process reveals the value of PYX3 which is 0,340 and the value of sig probability 0.27 which is smaller than 0.05 . This values tell that the effect of $\mathrm{X} 3$ variable (teachinglearning process) on $\mathrm{Y}$ variable (student's economics learning outcomes) is significant. A better teaching-learning process will result in better students economics learning outcomes. 
d. Effect of other variables

The effect of other variable is tested by using following formula:

$$
\begin{aligned}
\mathrm{PX}_{3_{\varepsilon^{1}}} & =\sqrt{ } 1-\mathrm{R}^{2} \mathrm{Y}_{11 \times 2} \\
& =\sqrt{ } 1-0,609 \\
& =\sqrt{ } 0,625 \\
& =0,791
\end{aligned}
$$

The calculation shows that the effect of other variables other than $\mathrm{X}_{1}, \mathrm{X}_{2}, \mathrm{X}_{3}$ variables on learning outcomes $(\mathrm{Y})$ scores $62.5 \%$. Based on those cofficient values of the path, an equation is

\begin{tabular}{|c|c|}
\hline No & Annotation \\
\hline
\end{tabular}
made.

$$
\begin{aligned}
Y & =\operatorname{PYX}_{1} X_{1}+\operatorname{PYX}_{2} X_{2}+\operatorname{PYX}_{3} X 3+\operatorname{PY}_{\mathcal{E}^{2}} \\
& =0,414 X 1+0,281 X 2+0,340 X 3+0,791
\end{aligned}
$$

Table 4. The summary of independent variable's effect on dependent variable

1 Direct-effect of principal's leadership $\left(\mathrm{X}_{1}\right)$ on economics learning outcomes $(\mathrm{Y})$

$\%$.

2 The effect of principal's leadership $\left(\mathrm{X}_{1}\right)$ on economics learning outcomes $(\mathrm{Y})$ when mediated by teaching-learning process $\left(\mathrm{X}_{3}\right)$

5.57

$\%$

Direct and indirect effect of principal's leadership variable $\left(X_{1}\right)$ on economics learning outcomes $(\mathrm{Y})$ $22.7 \%$

3 Direct effect of school climate $\left(\mathrm{X}_{2}\right)$ on variable of economics learning outcomes $(\mathrm{Y})$

4 The effect of school climate $\left(\mathrm{X}_{2}\right)$ on variable of economics learning outcomes $(\mathrm{Y})$ when mediated by variable of teaching-learning process $\left(X_{3}\right)$

Direct and indirect effect of variable of school climate $\left(\mathrm{X}_{2}\right)$ on variable of economics learning outcomes $(\mathrm{Y})$

5 Direct effect of variable of teaching-learnig process $\left(X_{3}\right)$ on variable of economics learning outcomes $(\mathrm{Y})$ The effect of other variables on variable of economics learning outcomes $(\mathrm{Y})$

$\begin{array}{llll}6 & \text { The effect of other variables on variable of economics learning outcomes }(\mathrm{Y}) & 62.5 & 62.5\end{array}$

Source : Primary data processing, 2017

From table 4, it can be seen that direct effect of principal's leadership on student's economics learning outcomes is great compared to indirect effect of principal's leadership on the student's learning outcomes variable through teaching-learning process. The same goes to variable of school climates' effect on student's economics learning outcomes. The direct effect of school climate on student's learning outcomes is greater than indirect effect of school climate on student's learning outcomes if accompanied by variable of teaching-learning process.

So, it means that variable of teaching-learning process is not an interverning variable. The reason is that principal's leadership and school climate are not able to improve the quality of teaching-learning process which is hoped to be able to improve student's economics learning outcomes at SMA N in Padang City. 
Hypothesis testing also found that student's economics learning outcomes can be affected by principal's leadership, school climate and teaching-learning process. This finding is in line with the result of research conducted by Isti Septiani (2013) and research by Karen (2010) which found a positive relationship between principal's leadership and student's learning outcomes.

The third finding of this research tells that school climate affects student's learning outcomes. Moreover, this finding agrees with the oponion stated by Mulyasa (2012) who explains that principal's leadership has an influence on school performance as a whole. Student's academic achievement might be predictable by seeing leadership of the principal. If principal's leadership is good, then student's academic achievement might also be good.

\section{Conclusion}

Finally, this paper comes to its conclusion part. According to findings and discussion above, there are some conclusion can be drawn. First, principal's leadership and school climate in SMA N in Padang City have a significant and positive effect on student's learning outcomes. It means, the better principal's leadership is, the better learning outcomes are.

Second, principal's leadership, school climate and teaching-learning process significantly and positively affect economics learning outcomes of students at SMA N in Padang. In other words, the effect variants of student's economics learning outcomes are the contribution of principal's leadership, school climate and teaching-learning process in SMA N in Padang City.

\section{Acknowledgments}

I would like to thank for my entire Professor (Prof. Dr. Syamsul Amar, M.S. and Dr. Idri, M.Si.) whom supporting me to do the research. All of them were inspiring me to complete my study. I also would like to thank for the teacher of economic at state senior high schools in Padang City and academician who involved the research.

\section{References}

Mulyasa. (2011). Manajemen dan Kepemimpinan Kepala Sekolah. Jakarta : Bumi Aksara.

Mulyasa. (2011).Menjadi Kepala Sekolah Profesional. Bandung : Remaja Rosdakarya.

Mulyasa. (2012). Manajemen Berbasis Sekolah :Konsep Strategi Dan Implementasi. Bandung: Remaja Rosdakarya.

Riduwan. (2009). Belajar Mudah Penelitian Untuk Guru-Karyawan dan Peneliti Pemula. Bandung: Alfabeta.

Riduan dan Kuncoro. (2011). Analisis Jalur (path Analisys). Jakarta : Alfabeta

Sugiyono. (2012). Metode Penelitian Kuantitatif, Kualitaif, dan RED. Bandung: Alfabeta.

Wahyudi. (2009). Kepemimpinan Kepala Sekolah : Dalam Organisasi pembelajaran (Learning Organization).

Bandung : Alfabeta. 